\title{
COMMITMENT OF INDEPENDENT AND INSTITUTIONAL WOMEN \\ DIRECTORS TO CORPORATE SOCIAL RESPONSIBILITY REPORTING
}

\begin{abstract}
This paper examines how independent and institutional women directors on boards affect corporate social responsibility (hereafter CSR) reporting. Most of the previous empirical evidence has shown a linear association between female directors and CSR disclosure, but to the best of our knowledge, no research has investigated the individual effect of independent and institutional female directors on CSR reporting. Therefore, the analysis of how the disclosure of CSR information is affected by independent and institutional women directors in a separate way merits our attention. Thus, we posit that there is a non-linear association, concretely quadratic, between independent and institutional female directors on boards and CSR reporting. Our results demonstrate that, in line with the monitoring hypothesis, as the presence of independent and institutional women directors on boards increases, CSR disclosure improves, but when their presence on boards reaches a tipping point $(20.47 \%$ and $13.32 \%$, respectively), CSR reporting decreases, which is consistent with the collusion hypothesis. This research contributes to existing literature on the relationship between board gender diversity and CSR disclosure by suggesting that board structures formed by institutional and independent female directors have an effect on CSR reporting. Hence, female directors play a relevant role on boards since they may influence CSR disclosure.
\end{abstract}

KEYWORDS: Corporate social responsibility, independent female directors, institutional female directors, agency theory, social identity theory, curvilinear relationship

JEL CODES: M14, G30, G34 


\section{INTRODUCTION}

According to Gray et al. (1996), CSR reporting is "the process of communicating the social and environmental effects of organisations' economic actions to particular interest groups within society and to society at large". In other words, through CSR reporting, companies voluntarily disclose to stakeholders and society the environmental and social impacts caused by their daily activities (e.g., Hammann et al., 2009; Jamali \& Neville, 2011; Jamali et al., 2015; Vashchenko, 2017), going beyond the financial figures of interest to investors to describe firms' relations with their stakeholders The disclosure of CSR information is not enforced by a specific law, but international bodies such as the Global Reporting Initiative (GRI) make recommendations on CSR matters.

Relevant decisions regarding CSR issues are approved by boards and, therefore, board composition is considered one of the most important tools for promoting CSR reporting (Muttakin et al., 2016). Samara et al. (2018) also support the significant role played by the board of directors in promoting CSR initiatives, specifically the environmental and social performance of family firms. The authors show that two governance structures of family businesses improve environmental and social performance: the combination of different levels of family involvement in the business with (1) outsiders on the board and (2) a high family presence on the board. Among the board attributes that may affect CSR disclosure, board gender diversity has received growing interest from scholars. Board gender diversity may imply a variety of opinions and ideas, which may affect CSR disclosure because a firm's stakeholders are not a homogeneous group (Catalyst, 1995). Women empathise with stakeholders and show a higher sensitivity towards their demands and needs, thus demonstrating a greater concern for social and environmental matters. Taking these views into consideration and given that the female leadership style differs from that of males (e.g., Manzoor \& Abrar, 2011; Alonso-Almedia et al., 2017), we expect that female and male directors will behave in different ways regarding CSR disclosure.

Past research has examined the impact of independent (Cuadrado-Ballesteros et al., 2015a) and institutional directors (Dimson et al., 2015) on CSR disclosure, but it has not differentiated between female and male directors. Researchers have also paid little attention to the effect of female directors' typology on CSR reporting. As far as we know, a few authors, such as Cabeza-García et al. (2017), have attempted to analyse the effect of outside female directors and independent female directors on CSR disclosure, but no research has investigated the individual effect of independent and institutional women directors on CSR reporting. These female directors are not directly involved in the management activities of 
companies, but there are some differences among them and, therefore, their incentives and engagement with CSR reporting may differ. Accordingly, the examination of how the reporting of CSR matters is affected by outside female directors (independent and institutional) in a separate way also merits our attention.

Combining a non-linear association, women directors' typology and CSR disclosure, we aim to explore whether there is a non-linear relationship between independent and institutional female directors and the reporting of CSR information. Hence, the paper addresses the following research question: How does the presence of female directors on the board affect CSR reporting?

Our results show that as the proportions of independent and institutional female directors on boards grow, CSR reporting also increases, which is consistent with the monitoring hypothesis; however, with the inclusion of additional independent and institutional women directors beyond a tipping point $(20.47 \%$ and $13.32 \%$, respectively), CSR disclosure decreases, which is in line with the collusion hypothesis. Thus, our findings suggest a nonlinear association between outside women directors and CSR disclosure. This evidence confirms the importance of outside female directors (independent and institutional women directors) for CSR disclosure in Spain, where there are still high levels of ownership concentration, a lack of protection for minority shareholders and a lack of transparency in financial and non-financial information disclosure. Therefore, the most relevant innovation of this paper, in comparison to the preceding research that reports that independent female directors affect CSR disclosure either positive or negatively (a linear association), or that does not explore the effect of institutional female directors on CSR reporting, is that Spanish boards of listed firms made up by independent and institutional women directors will encourage or discourage CSR reporting depending on their representativeness on boards, which is consistent with a non-linear relationship.

This study contributes to the growing CSR and gender diversity literature in several ways. Firstly, examining board structures with institutional and independent directors extends the knowledge of the types of female directors and their representativeness on boards that leads to better CSR reporting. Our paper is, to the best of our knowledge, the first to investigate the individual impact of both types of women directors on CSR disclosure in a non-linear way. Secondly, by analysing how diverse types of female directors on boards impact CSR reporting, we have tried to heed the call for exploring the effect of board gender diversity on CSR commitments in order to extend the scope of this analysis beyond the Anglo-Saxon context (Jain \& Jamali, 2016). Thirdly, we contribute to the debate on how independent and 
institutional female directors may impact CSR reporting, by combining two competing views (agency theory and social identity theory) and by reconciling past paradoxical findings regarding female involvement on boards and CSR disclosure. Prior literature has focused on different theoretical perspectives to analyse board gender diversity and CSR reporting, but it seems to have disregarded social and psychological aspects, which indicate that female and male directors behave differently when making business decisions. Finally, our evidence may alert listed non-financial firms' shareholders, potential investors, policymakers, stakeholders and managers to the most appropriate gender representation on boards for encouraging CSR disclosure.

\section{THEORETICAL FRAMEWORK}

There are several competing views of the effect of women directors on CSR disclosure. Among them, the most common are the agency and resource dependency approaches. In this sense, agency theory postulates that the efficient supervisory role performed by female directors on boards will reduce information asymmetries, increasing CSR disclosure and, consequently, mitigating agency problems between managers and stakeholders (e.g., RegueraAlvarado et al., 2015). The resource dependence approach argues that female directors, given their capacity to maintain outside connections with stakeholders and organisations, will positively affect CSR disclosure because their presence on boards is a relevant tool for firms to gain legitimacy with stakeholders and society (Lückerath-Rovers, 2013). Theories which explore board gender diversity and CSR disclosure from a social, behavioural and psychological perspective have been disregarded by some of the prior research, but they provide relevant theoretical arguments for examining such a relationship. Gender socialisation theory suggests that a female leadership style is more ethical and social than that of males and is thus more likely to be orientated towards stakeholders, therefore increasing CSR reporting (e.g., Landry et al., 2016). However, social identity theory posits that when the presence of women directors on boards goes from moderate to higher levels, they will be more likely to reduce CSR reporting because they will be classified as out-group members (boards with males and females) instead of in-group members (boards with a majority of males), performing better in-group than out-group (e.g., Nielsen \& Huse, 2010). Our viewpoint, which is in line with Thomsen and Conyon (2012), is that most of these different perspectives are more complementary than contradictory. In this regard, from the agency, resource dependence and gender socialisation theories, a positive linear association can be predicted between board gender diversity and CSR disclosure, while a negative linear association can 
be predicted from the social identity approach, and an inverted U-shape curvilinear association can be expected from an integration of agency theory, for instance, through the social identity approach (Ali et al., 2014). Thus, the positive or negative effect of female directors on CSR disclosure will depend, according to the theoretical integration employed, on the representativeness of female directors on boards (Ali et al., 2014; Richard et al., 2007).

A relevant stream of empirical research supports the thesis that there is a positive or negative linear relationship between female directors and CSR reporting (e.g., Dobbin \& Jung, 2011; Fernández-Feijoo et al., 2012, 2014a; Alonso-Almeida et al., 2017) or there is no significant association (e.g., Shukeri et al., 2012). This inconclusive evidence suggests that research should be based on contrasting approaches (a positive and negative linear association), which will propose a curvilinear relationship (Ali et al., 2014). To the best of our knowledge, there is no research focused on exploring a non-linear relationship that is concretely curvilinear between board gender diversity and CSR disclosure, which can be supported by the integration of agency theory with social identity theory. Thus, against such a backdrop, we wonder whether there is a non-linear association between women directors and CSR disclosure.

Corporate governance codes and laws, particularly those in Spain, generally classify board directors' typology between insiders and outsiders, who can be represented by women and men. According to the Spanish Unified Code of Corporate Governance (UCCG, 2006), which was updated by the Good Governance Code of Listed Companies (GGC, 2015), insiders are executive directors directly involved in a firm's management, and outside directors can be split between independent and institutional directors, who have different agendas and incentives for controlling managers. Independent directors are professionals in a workplace totally outside the company and are interested in showing the responsible behaviour of firms. They do not have social relationships with firms or the families that run them, except in a professional capacity, and therefore they can perform their tasks without pressure from the firm, managers and dominant shareholders. Additionally, independent directors represent minority shareholders' interests or dispersed ownership, protecting their rights with respect to the agency costs of controlling shareholders (Ferrarini \& Filippelli, 2013). Independent directors are interested in protecting their reputation and credibility, which will depend on the extent to which companies are socially responsible and, accordingly, they will be more likely to disclose CSR information that signals to stakeholders their engagement with CSR matters. Institutional directors represent controlling shareholders and might have professional or personal relations with companies. Given the high ownership concentration of the Spanish 
listed firms, dominant shareholders take important positions on boards, have a long-term horizon and have a strong influence on management (e.g., Pucheta-Martínez \& LópezZamora, 2017). The role performed by institutional investors who serve as directors on boards allows them to take part in the decision-making process of firms as shareholders and directors (e.g., Weinstein \& Yafeh, 1998). These directors are considered strategic directors (e.g., Oh et al., 2011) since they may provide experience and guidance, connect firms with relevant stakeholders or significant external agents, obtain external resources and formulate strategic or other important decisions of firms (Shaukat et al., 2015). Thus, institutional directors are concerned with disclosing more company information in order to maintain the prestige and public image of a company, and therefore, they tend to demonstrate active behaviour towards CSR matters by integrating environmental, social and ethical issues into businesses (Wen, 2009) in order to demonstrate commitment to stakeholders. Hence, they will try to satisfy stakeholders' needs by encouraging the management team to report CSR issues.

Based on agency theory, shareholders may demand external mechanisms such as voluntary CSR disclosure (Fernández-Feijoo et al., 2014a; Jo et al., 2016) in order to monitor managers' functions and obtain greater transparency of financial or non-financial information. In this sense, the agency approach assigns the board the traditional role of representing shareholders and protecting them from managers (Griffin, 2017). In this regard, board composition has a relevant role in the decision-making process (Hassan et al., 2018) since it reduces agency costs and encourages CSR disclosure. Specifically, outside directors (independent and institutional) do not have a link with the company, so they tend to disclose more social and environmental information to society and other stakeholders because they are not usually aligned with managers. In addition to outsiders, agency theory also postulates that board gender diversity is a key attribute, as female directors on boards tend to be more transparent and accountable (Luoma \& Goodstein, 1999). This renders women directors as a relevant corporate governance mechanism for controlling managers (Carter et al., 2003), since they will be more likely to mitigate agency problems (Hillman \& Dalziel, 2003), thus reducing information asymmetries through the disclosure of CSR issues. This approach also argues that board gender diversity may provide a greater variety of opinions, ideas, values, expertise, experience and backgrounds, as well as different perceptions and sensitivity to CSR matters. This might impact on the disclosure of CSR information since stakeholders linked with a company comprise a heterogeneous group (Catalyst, 1995). Given that stakeholders' interests differ and are not always aimed in the same direction, as the presence of women directors increases on boards, they will become more heterogeneous, which will therefore make it 
possible to better understand stakeholders' needs (Ayuso \& Argandoña, 2007). According to Eagly et al. (2003) and Cuadrado-Ballesteros et al. (2015b), women directors are characterised by their empathy, communication skills, participation and cooperation, which lead them to have greater concern for social and environmental matters, which may positively impact CSR reporting (e.g., Kesner, 1988). Thus, when female directors on boards rise from low to moderate levels, the benefits go on improving, in line with that suggested by Knouse and Dansby (1999), and female directors on boards might have a positive impact on CSR reporting (e.g., Fernández-Feijoo et al., 2014b; Liao et al., 2016) because they are considered to be more benevolent and less power-orientated than their male counterparts (Adams \& Funk, 2012).

Nevertheless, when the percentage of female directors increases from moderate to higher levels, they will categorise themselves and others, given that gender diversity is considered a demographic factor (Lau \& Murnighan, 1998), as either in-group (board directors with the same demographic group: normally the majority, males) or out-group (board directors with a different demographic group: female and male directors) (e.g., Nielsen \& Huse, 2010; Terjesen et al., 2009), which is consistent with social identity theory. Individuals who are considered part of the out-group find it more difficult to join with those who are in-group (Tajfel \& Turner, 1986). Individuals who are part of the in-group tend to interact and perform better than those who are in the out-group because they consider themselves as superior, trustworthy, honest and cooperative (McNamara et al., 2017; Nielsen \& Huse, 2010), thus undermining the contributions of the out-group (Wire, 2010), because their (the in-group) behaviours towards the out-group will be negative. Traditionally, boards have been dominated by males, and therefore, as Nielsen and Huse (2010) indicate, "women are likely to be perceived as out-group members" because they are the minority on most boards, performing worse than if they were part of the in-group. Out-group members tend to stereotype and negatively assess the skills of their cohort, creating a bias that causes members to undervalue the contributions of minorities such as female directors (Mackie, 1987; Miller \& Brewer, 1996). The interaction between board members generates an intergroup dynamic, which impacts on the development and outcome of the group, depending on the effects that the heterogeneous relations may cause, such as coalitions, divergences, conflicts, cooperation, confrontation or polarisation, among others, as social identity theory suggests (Tajfel \& Turner, 1986). Therefore, male directors who share seats on boards with women directors might demonstrate uncooperative behaviour, resulting in intergroup divergence or decreasing intergroup support, communication and collaboration (Pelled, 1996; Kravitz, 2003). These 
negative attitudes reduce board effectiveness because intergroup interactions are unproductive, consequently leading to reduced CSR disclosure. Thus, as women directorship increases, male directors will have to share power with their female counterparts, who possess different abilities and social competences, which may cause divergent processes and dissatisfaction with the organisation. Consequently, this might lead to negative individual performances (e.g., reduced productivity or sales), resulting in adverse group repercussions that negatively affect company outcomes, such as CSR disclosure.

Hence, drawing on the integration of the agency perspective with the social identity approach, as the presence of outside female directors (independent and institutional) increases, firms become more likely to disclose CSR information. However, beyond a certain inflection point, more independent and institutional women directors on boards will reduce the disclosure of CSR information. Thus, from low to moderate levels of gender diversity, it will be beneficial, but from moderate to high levels of gender diversity, it will be detrimental.

\section{HYPOTHESES DEVELOPMENT}

\section{Independent female directors and CSR reporting}

The UCCG (2006) and the GGC (2015) claim that independent directors should not have any relationship with a company in such a way that might influence their opinions or functions. Independent directors are a key mechanism for monitoring and controlling firms' managers and board effectiveness (Wang et al., 2015). For this reason, the inclusion of independent directors on boards can be considered a link between a company and its environment and can promote CSR reporting, thus improving a firm's long-term success. Harjoto and Jo (2011) and Fernández-Gago et al. (2016) demonstrate that independent directors on boards can put pressure on firms in order to ensure congruence between organisational values and social activities, thus contributing to an increase of both CSR disclosure and market value. Additionally, independent directors will be willing to show their commitment to stakeholders through the reporting of CSR information because they are concerned about their image, legitimation and reputation. We extend these perspectives to independent female directors since the agency approach suggests that women directors may reduce agency costs by disclosing CSR information. Papers by Al-Shaer and Zaman (2016) and Hyun et al. (2016) show that independent female directors have a positive effect on CSR issues, showing a linear relationship between independent women directors and CSR reporting. This evidence suggests that as the presence of independent female directors increases, there is a higher likelihood of reporting CSR information. 
However, according to social identity theory, the addition of independent female directors beyond a certain threshold may result in a decrease of reporting of CSR matters since they will be categorised as the out-group, performing worse than if they were classified as part of the in-group, suggesting a non-linear relationship between independent female directors and CSR reporting. In addition to this, Fligstein (1991) also suggests that the financial know-how of independent directors is one of the main reasons for appointing them. Moreover, independent directors do not maintain investment or business links with companies and their shareholders. Thus, these directors are better able to analyse financial issues than other information, such as CSR matters. Consequently, board independence may be negatively associated with CSR disclosure, as supported by Cuadrado-Ballesteros et al. (2015a). GarciaSanchez et al. (2014) provide evidence that independent directors disagree with disclosing CSR information since this could affect their professional reputation, especially given that they are not experts in CSR matters, as Haniffa and Cooke (2005) and Mohamad et al. (2011) also show. Thus, when the proportion of independent female directors on boards exceeds a certain threshold, it might be detrimental for addressing CSR matters, not only because they are categorised as the out-group, but also because independent female directors may be perceived by their male counterparts as not having the appropriate expertise related to CSR issues. As far as we know, no prior research has explored a non-linear association between independent women directors and CSR reporting. Therefore, we have attempted to fill this gap by integrating agency theory with social identity theory, and accordingly, we formulate the following hypothesis:

Hypothesis 1: As the proportion of independent female directors on boards increases, CSR reporting is increased; however, beyond a tipping point, more independent women directors will have a negative impact on CSR reporting

\section{Institutional female directors and CSR reporting}

Institutional directors on boards represent dominant investors, such as institutional investors. According to agency theory, these investors become actively involved with management activities, leaving their passive roles regarding the supervision of managers (Ivanova, 2017). Additionally, institutional investors constitute one of the most important elements in the corporate decision-making process (Ruiz-Mallorquí \& Santana-Martín, 2011).

With regard to CSR disclosure, institutional investors guarantee sustainable actions of firms in the longer term (Bolton et al., 2002) and enhance CSR reporting (Harjoto et al., 2015; Hwang et al., 2015), which help achieve long-term success and benefits for the company. 
Dyck et al. (2015) find that institutional investors prefer to represent companies involved with CSR issues because one of their main priorities is to consider CSR responsibilities in the investment decisions of firms, instead of prioritising firms' economic benefits. In addition, institutional investors tend to secure changes in CSR-related shareholder proposals (Del Guercio \& Tran, 2012) and voting engagements on CSR issues (Dimson et al., 2015). Dhaliwal et al. (2011) documented that voluntary CSR disclosure in companies tends to attract institutional investors, who play monitoring and governance roles and have long investment horizons. Authors such as Neubaum and Zahra (2006), Zattoni (2011) and Pucheta-Martínez and López-Zamora (2017) find that institutional directors encourage CSR reporting.

However, the relation between institutional investors and CSR disclosure may be negative. Arora and Dharwadkar (2011) and Ghabayen et al. (2015) show that institutional shareholding has a significant and negative effect on CSR reporting, since institutional investors may engage in opportunistic behaviours in order to enjoy private benefits; they may work together with managers and, as a consequence, may reduce the monitoring functions in their governance. Furthermore, Chava (2014) reports that firms' environmental issues are negatively affected by institutional ownership.

Thus, according to this literature, we argue that effective control mechanisms on boards by institutional investors may have both positive and negative effects on CSR disclosure in a linear way. However, Feng and Song (2013) demonstrate a non-linear association, specifically a quadratic arrangement, between institutional investors and CSR disclosure, as a combined result of the monitoring and entrenchment hypotheses. Harjoto et al. (2015) also find a nonlinear association between institutional ownership and CSR disclosure, suggesting that active institutional investors exert a quadratic influence on CSR reporting. Thus, when institutional directorship is low, the monitoring hypothesis prevails, as it is positively associated with CSR reporting and, as a consequence, institutional directors perform an active role in encouraging managers and other directors to disclose CSR information. However, if the proportion of institutional directors on boards reaches a certain threshold, the entrenchment or collusion hypothesis prevails, and they are negatively associated with CSR disclosure, given that they prefer to achieve absolute control of firms, which may unfavourably impact CSR disclosure.

We extend the above views to the role of institutional female directors on boards. To the best of our knowledge, there is no prior evidence on how institutional women directors on boards affect CSR reporting. Drawing on the agency perspective, we expect a positive effect of institutional female directors on CSR reporting as their presence on boards increases, since 
they will play a role in supervising and monitoring respective managers' behaviour. However, institutional women directors will negatively affect the disclosure of CSR information when their representation exceeds a tipping point, according to social identity theory, given that they will be classified as an out-group, performing worse than if they were the in-group. Accordingly, we propose the following hypothesis:

Hypothesis 2: As the proportion of institutional female directors on boards increases, CSR reporting is increased; however, beyond a tipping point, more institutional women directors will negatively impact on CSR reporting

\section{METHODOLOGY}

\section{Sample}

The sample is composed of 152 Spanish non-financial listed firms over the period 20042014. Financial companies were excluded from the sample because they use unique accounting, which is difficult to compare with industrial companies, and because they are regulated by financial authorities using special norms. Thus, the final sample includes a panel data of 1,312 firm-year observations. As Arellano (2003) shows, our unbalanced panel data might report findings that are as consistent as those provided by balanced panel data.

We built our database from the following sources. The CSR data was obtained from the GRI web page and from the corporate web pages of the companies. The GRI is considered a relevant instrument for providing important information concerning financial, environmental and social issues (Fernández-Feijoo et al., 2014a). Then, we collected the CSR information from two sources: the GRI web page and companies' web pages. The financial data (ROA, LEV and SIZE) was collected from the "Sistemas de Análisis de Balances Ibéricos" (SABI) database, and the corporate governance data (INDEP_WOM, INST_WOM, INDEP, INST, OWNCON and BDSIZE) was obtained from the Public Register of the Spanish Securities Market Commission (CNMV), specifically from the corporate governance annual reports that Spanish listed companies are required to disclose. The annual corporate governance report allowed us to ascertain how directors (in our case, female directors) are considered independent versus institutional.

\section{Variables}

Our dependent variable is defined as CSR_INDEX and is measured as an average score derived from the ratio between the aggregation of the following five items of CSR - each one measured as a dummy variable - and the total five items analysed: (1) disclosure of CSR 
information by any means - that is, this item will be given a value of 1 if a firm discloses information on social and environmental matters on its home page using its own reports and/or discloses this information using the GRI report, with 0 given when firms do not report CSR information in any case; (2) disclosure of CSR information through non-GRI reports i.e., this item will be given a value of 1 if a firm does not disclose CSR information using the GRI reports (firms do not follow the pattern or format of report recommended by the GRI), but it does provide this information according to its own criterion and on its own home page with its own report, with 0 given otherwise; (3) disclosure of CSR information through the GRI reports - that is, this item will be given a value of 1 if a firm discloses social and environmental information using the format or pattern of report recommended by the GRI, but the companies may also provide this information by other means, with 0 given otherwise; (4) the CSR report is certified (checked) by the GRI - that is, this item will be given a value of 1 if the GRI report used by a firm to disclose social and environmental information is checked by the GRI, with 0 given otherwise; and (5) the CSR information is also audited by an external and independent body (external assurance) - that is, this item will be given a value of 1 if the CSR information disclosed by a firm is audited by an independent and external body, with 0 given otherwise. This measure has been created according to the method of analysis of CSR used by Alonso-Almeida et al. (2015), Dong et al. (2014), Harjoto et al. (2015) and Lock and Seele (2016), among others. In Table 1, we show the classification of firms, according to the values of the CSR index ranging from 0 to 1 :

\section{$<$ Insert Table 1 here $>$}

We have used the following independent variables. The proportion of independent women directors is defined as INDEP_WOM, and the proportion of institutional women directors is designated as INST_WOM. The quadratic terms of both variables are labelled as INDEP_WOM ${ }^{2}$ and INST_WOM ${ }^{2}$ and are calculated as the square of the proportion of institutional and independent women directors on boards, respectively.

The following control variables have been employed. INDEP and INST represent the proportion of independent and institutional directors on boards (Harjoto et al., 2015), respectively. To analyse the effect of ownership concentration, we define OWNCON, which is measured as the proportion of shares held by shareholders holding at least $10 \%$ of a firm's stock, and BDSIZE is measured as the total number of directors serving on boards (CuadradoBallesteros et al., 2015a). Firm performance is denoted by ROA. Another control variable used is leverage, defined as LEV. Firm size (e.g., Rodríguez-Ariza et al., 2017), defined as SIZE, is also controlled for ( $\mathrm{Li} \&$ Chen, 2018). Finally, we have taken into account the 
business sector, defined as SEC, which is calculated as a dummy variable that equals 1 if the company belongs to the sector analysed, with 0 otherwise. We have used the industry classification set up by the CNMV, described in Table 2, where we offer a summary of all the variables employed and the way in which they have been operationalised.

\section{$<$ Insert Table 2 here $>$}

Thus, we propose the following model:

$\mathrm{CSR}_{-} \mathrm{INDEX}_{\mathrm{it}}=\alpha+\beta_{1} \cdot \mathrm{INST}_{-} \mathrm{WOM}_{\mathrm{it}}+\beta_{2} \cdot \mathrm{INST}_{-} \mathrm{WOM}_{\mathrm{it}}{ }^{2}+\beta_{3} \cdot \mathrm{INDEP}_{-} \mathrm{WOM}_{\mathrm{it}}+$ $\beta_{4} \cdot \mathrm{INDEP}_{-} \mathrm{WOM}_{\mathrm{it}}{ }^{2}+\beta_{5} \cdot \mathrm{INDEP}_{\mathrm{it}}+\beta_{6} \cdot \mathrm{INST}_{\mathrm{it}}+\beta_{7} \cdot \mathrm{OWNCON}_{\mathrm{it}}+\beta_{8} \cdot \mathrm{BDSIZE}_{\mathrm{it}}+\beta_{9} \cdot \mathrm{ROA}_{\mathrm{it}}+$ $\beta_{10} \cdot \mathrm{LEV}_{\mathrm{it}}+\beta_{11} \cdot \mathrm{SIZE}_{\text {it }}+\beta_{12} \operatorname{SEC}(\mathrm{i})_{\mathrm{it}}+\mu_{\mathrm{it}}+\varepsilon_{\mathrm{it}}$

where year and firm fixed effects are represented by $\mu_{\text {it }}$ and the error by $\varepsilon_{\text {it }}$. Firm fixed effects take into account regular and non-observable features of firms that may be associated with CSR reporting.

The most suitable methodology for estimating this model is the Tobit regression for panel data, because it allows us to consider a dependent variable with limits on the left or right censoring. The dependent variable in our research, CSR_INDEX, ranges between 0 and 1 , inclusive. Accordingly, this variable is censored on two sides (0-1), and therefore, the most appropriate regression for testing our hypotheses is a Tobit model.

\section{RESULTS}

\section{Descriptive statistics and correlations}

The descriptive statistics of the dependent, independent and control variables are presented in Table 3. This table reports that the CSR disclosure of Spanish non-financial listed firms is, on average, 0.15 out of 1 . This value shows that the level of CSR information disclosed by Spanish listed firms is moderate. According to board composition, we can observe that the proportions of independent and institutional directors represent, on average, $30.27 \%$ and $44.70 \%$, respectively, while the proportions of independent and institutional women directors on boards represent, on average, $3.18 \%$ and $4.55 \%$, respectively. These results suggest that institutional directors and institutional women directors have more representation on boards than independent directors and independent female directors. The ownership concentration represents, on average, $43.67 \%$, the board size is, on average, 10.20 members, and the firm size is, on average, 10.56 ( $\log$ of the total sales, expressed in thousands of euros). Moreover, the return on assets is, on average, $2.56 \%$, and the leverage of firms is, on average, $53.20 \%$. 
With regard to industries, on average, the "other" manufacturing industry is the highest represented sector, with $23.55 \%$, and the least represented sector is agriculture and fisheries, with $1.60 \%$.

\section{$<$ Insert Table 3 here $>$}

For the sake of brevity, the correlation coefficients for all the variables used in this analysis in order to check for multicollinearity are not reported. The correlations in pairs of all the variables are not greater than 0.80 (Carcello \& Neal, 2000). Therefore, based on these results, we can affirm that multicollinearity concerns do not arise.

\section{Regression results}

Table 4 presents the results of the Tobit regression. As you can see, we built two models and they are statistically significant. In Model 1, we analyse how independent women directors on boards affect CSR disclosure, while in Model 2, we investigate the relationship between institutional women directors on boards and CSR reporting.

In Model 1, the variables denoting independent women directors on boards in a linear (INDEP_WOM) and non-linear way (INDEP_WOM ${ }^{2}$ ), which are concretely quadratic (nonlinear), present the expected signs and are statistically significant, as predicted. Thus, according to this result, the first hypothesis cannot be rejected as it appears that the presence of independent women directors on boards increases CSR disclosure. However, as the representation of independent female directors on boards exceeds a tipping point $(20.47 \%)$, CSR reporting is negatively impacted. Some past research provides evidence that independent directors enhance CSR disclosure (Harjoto \& Ho, 2011; Fernández-Gago et al., 2016), while authors such as Garcia-Sanchez et al. (2014) and Cuadrado-Ballesteros et al. (2015a) report that these directors have a negative effect on CSR reporting. Our results support the monitoring hypothesis, because increases in the proportion of independent women directors on boards up to a certain point may encourage CSR reporting. However, when the percentage of independent female directors exceeds this point, they might collude with managers and support their decisions, consistent with the collusion hypothesis, which may not be in line with promoting CSR disclosure. Consequently, it will be more likely that CSR reporting decreases.

In Model 2, the variables of institutional women directors on boards present a linear (INST_WOM) and non-linear (INST_WOM ${ }^{2}$ ) relation, exhibiting the expected signs, and are statistically significant. Hence, our empirical findings are consistent with Hypothesis 2, which suggests that the disclosure of CSR information improves as the proportion of institutional 
women directors on boards increases, but only up to a point $(13.32 \%)$, beyond which further increases are associated with decreases in CSR disclosure. This idea is confirmed by Frink et al. (2003), who show that the optimal proportion of women directors on boards occurs when it is balanced. In line with institutional directors, authors such as Feng and Song (2013) and Harjoto et al. (2015) report a non-linear relationship between institutional ownership and CSR reporting, because they consider social activities as a priority in their investment decisions. In line with the findings obtained for independent female directors, our evidence also supports the monitoring and collusion hypotheses with institutional female directors. In this regard, as the presence of institutional female directors on boards increases, there is a higher probability that they positively influence CSR disclosure; but when their presence on boards reaches a turning point, this situation will invert (collusion hypothesis) and they may support executive teams' decisions focused on other socio-economic decisions that do not consider CSR disclosure as a main strategy to increase firm performance.

Regarding control variables, we can appreciate that independent directors (INDEP), ownership concentration (OWNCON), board size (BDSIZE), return on assets (ROA), leverage (LEV) and firm size (SIZE) present a positive sign and are statistically significant in the two models, with the exception of the proportion of independent directors, which is not statistically significant in Model 1. Additionally, the proportion of institutional directors on boards (INST) and the sector (SEC(i)) report a negative sign and are statistically significant in the two models. ${ }^{1}$ In Figure 1, we show a summary of our main findings.

$<$ Insert Table 4 here $>$
$<$ Insert Figure 1 here $>$

We also control for the potential endogeneity concerns between independent female directors, institutional female directors and CSR reporting, given that these problems might appear in research such as this (Villalonga \& Amit, 2006). Specifically, we would like to assess whether the proportion of independent and institutional women directors on boards leads to more or less CSR disclosure, or whether companies with more or less CSR disclosure may be more or less attractive for independent and institutional women directors. The causality between CSR reporting and these female directors is probably in the direction from directors to CSR disclosure, but it is also possible that the disclosure of CSR matters might impact board structure. The causality issue has been addressed by lagging measures of the independent variables, which is consistent with Hartzell and Starks (2003) and Ozkan (2007), who support the use of lagged explanatory variables to reduce potential endogeneity problems. The findings, not provided for the sake of brevity, are in line with the results 
obtained in the baseline model - that is, the estimates of the models with lagged explanatory variables confirm the earlier findings. Thus, the results suggest that the potential endogeneity is not a problem in our research.

\section{Sensitivity analysis}

To test the robustness of our findings, we ran the model using three different dependent variables: (1) the CSR_INDEX calculated as the aggregation of the five items of CSR considered, each one measured as a dummy variable; (2) the CSR_INDEX calculated as the ratio between each of six items - the five items considered in the dependent variable used in the baseline model plus an additional item - and the total six items (each item is computed as a dummy variable; the additional and sixth item takes into account whether the assurance scope refers to the entire CSR report; thus, this item will be given a value of 1 if the whole CSR report is verified, with 0 otherwise); and (3) the CSR_INDEX calculated as the aggregation of the six items of CSR considered in point (2), with each one measured as a dummy variable. The findings obtained, which are not reported for the sake of brevity, corroborate our predictions regarding the curvilinear relationship between independent and institutional female directors and CSR disclosure. Hence, our findings are robust, since they do not depend on the way that CSR reporting is measured in this research.

\section{DISCUSSION}

To explore how independent and institutional female directors on boards affect CSR reporting, while controlling for company characteristics, we conducted multivariate regression analyses. Consistent with our predictions, our results show a positive relationship between independent and institutional women directors on boards and the disclosure of CSR information, but when their presence on boards exceeds a certain threshold, the reporting of CSR issues decreases, suggesting a non-linear relationship. These findings are robust to various additional tests. Our evidence supports the view that the typology of women directors on boards (institutional and independent) becomes a driver or non-driver of CSR reporting, depending on their representation. It seems that institutional and independent female directors perform a supervisory role, monitoring managerial behaviour, when their presence on boards ranges from low proportions to a certain tipping point, in line with the monitoring hypothesis, as agency theory suggests. Thus, firms will remain sustainable if the presence of independent and institutional female directors on boards remains below a certain threshold, indicating that their engagement with CSR matters and their interest in mitigating agency problems due to 
information asymmetries may be reduced if more CSR information is disclosed. On the other hand, the findings also suggest that the collusion hypothesis prevails, undermining the control of managerial behaviours, as the proportion of independent and institutional female directors exceeds the tipping point, negatively impacting CSR reporting, which is consistent with social identity theory; consequently, firms will be less committed to CSR matters, stakeholders and society. Two opposite effects on CSR disclosure can be exerted by independent and institutional female directors on boards, which cannot be supported by a linear relationship, but rather by a quadratic relationship. Such a relationship suggests that there is an inflection point that might alter the correlation of internal forces of boards, impacting on the conflict or cohesion of the board intergroup (between female and male directors) or on the capability of a board's directors to have an effect (Ali et al., 2014). Among board directors, there is an intergroup dynamic that exposes the effects that heterogeneous members have on the group outcome, such as confrontation, cooperation, conflicts, alignment of interests and cohesion, among others. Our evidence also suggests that when the presence of institutional and independent female directors on boards goes from low levels to the turning point, the power is mostly concentrated with men directors, and there will be cooperation, alliances and communication intergroup. This positive interaction between women and men may explain the positive effect of institutional and independent female directors on the disclosure of CSR matters. However, when the presence of institutional and independent directors exceeds the inflection point, more independent and institutional women directors might lead to dissatisfaction among all directors, causing conflict and a lack of cooperation and support intergroup, in line with social identity theory. Therefore, intergroup interaction may have a negative effect on the reporting of CSR matters. In conclusion, our findings suggest that representation of institutional and independent female directors below the inflection point drives their efforts towards engaging in CSR issues to meet all stakeholders' expectations. These female directors may play an active and effective monitoring role and will tend to align their representatives' interests with those of other shareholders, trying to guarantee management involvement in CSR matters, avoiding negative and opportunistic disclosures and supporting those that benefit a broad range of stakeholders. However, the monitoring role played by institutional and independent female directors will be less effective and weaker when their presence on boards is higher than the critical point, since they will tend to enforce their own interests at the expense of other directors - specifically, male directors. Their aim will not be the enhancement of CSR disclosure, but rather obtaining private benefits and supervising male counterparts in order to hinder them from fulfilling their own aims. 
Therefore, institutional and independent female directors will be likely to collude with managers, supporting their decisions, and will be less willing to challenge the managers with regards to CSR disclosure. Managers may provide benefits to those institutional and independent female directors who do not hinder their decisions, such as limiting the reporting of CSR issues. Hence, this research offers sound guidance on the inclusion of independent and institutional female directors on boards and its effect on CSR disclosure.

\section{IMPLICATIONS, LIMITATIONS AND SUGGESTIONS FOR FUTURE RESEARCH DIRECTIONS}

This paper has both theoretical and practical implications. Firstly, our analysis can have substantial value for regulatory bodies, because it allows them to observe the clear evidence that there is under-representation of women on boards, and this is in spite of the fact that the proportion of independent and institutional women on boards tends to improve CSR disclosure until their presence reaches a certain inflection point. This research is framed in a context where the gender quota on boards is a recommendation for firms, as opposed to the mandatory quota implemented in some countries such as, for instance, Norway. Thus, our evidence may be relevant for regulators who should introduce laws or recommendations to enhance gender quotas on corporate boards, because an optimal proportion of institutional and independent female directors on boards promotes CSR reporting. Policymakers should recommend the representation of institutional and independent female directors on boards until a certain inflection point, since they behave as a monitoring mechanism that enhances CSR disclosure and, as a consequence, information asymmetries may be mitigated. Beyond this tipping point, it is not recommendable to add more institutional and independent women directors, since their presence will discourage CSR disclosure. Secondly, our research is timely and might be relevant for Spanish practitioners, as the new recommendations and laws issued regarding the presence of female directors on boards are not being properly implemented. As CSR disclosure is considered a strategic decision, managers should also pay more attention to board composition, specifically to the presence of outside female directors (independent and institutional female directors), given the repercussions for the reporting of CSR matters. Thus, managers interested in improving their reputation, tenure, success and legitimation by society, as well as avoiding pressure from dominant stakeholders and handling risk not merely with investment and financial strategies, but also with CSR strategies, may wish to signal their engagement with CSR issues to stakeholders and society. Accordingly, managers might consider having more independent and institutional female 
directors on boards until a certain threshold, as exceeding this inflection point will reduce CSR reporting. Companies should freely make up their boards, and in the case of institutional and independent women directors, they should consider suitable proportions to protect minority shareholders' rights against dominant shareholders' power, as well as playing an efficient supervisory role in enhancing CSR reporting. In the same way, stakeholders might also demand that firms improve gender diversity on boards, specifically increasing the proportions of independent and institutional female directors, since their presence on boards until a certain tipping point becomes an effective monitoring mechanism that promotes CSR disclosure. Finally, our findings may be useful for academics, since we consider CSR reporting as an essential duty of boards. In this regard, board directors have an impact on the decision-making process of firms and, therefore, will affect strategic decisions such as CSR disclosure. Researchers should explore more deeply what other kinds of female directors, as opposed to institutional and independent, affect CSR disclosure and how this effect occurs. Additionally, attributes other than the typology of women directors, such as their expertise, skills, backgrounds, ethics or sensitivity towards CSR matters, should be examined; this is despite the difficulty of measuring such characteristics.

Several limitations of this research should be noted. Firstly, in this analysis, we do not consider affiliate directors as outsiders, which is in contrast to other research (e.g., Samara \& Berbegal-Mirabent, 2017). Affiliates can be defined as directors who maintain or may maintain personal connections with companies and/or family owners. These include solicitors, financial advisors and experts, among others (e.g., Arosa et al., 2010), but they are not employees of the firm. The types of directors who made up Spanish listed firms' boards, insiders or outsiders (independent or institutional), are provided in the annual corporate governance reports that these firms have had to disclose since 2003. The fact that Spanish laws and corporate governance codes do not consider affiliate directors may explain why annual corporate governance reports do not provide information on these directors. For this reason, in this research, we only focus on independent female and institutional female directors, although both types of women directors might also be affiliate directors. Secondly, our database was built using industrial companies, so our results cannot be used to interpret the results of financial companies. Thirdly, our CSR reporting measure may be considered simplistic since it provides little information on the content, quality and extent of the reporting. Ultimately, in this research, we only consider CSR disclosure towards external stakeholders, but internal social responsibility (towards employees), as Samara and Arenas 
(2017) suggest, can be as meaningful as external social responsibility (towards the environment).

Hence, we suggest the following future research avenues. Firstly, as Jamali et al. (2017) suggest, it would be interesting to analyse the role of informal firms and micro-firms in CSR, as well as the informal aspects of CSR activities in small to medium-sized enterprises, combining this topic with board gender diversity. Secondly, the development of a more thorough CSR reporting measure, increasing the content, quality and extent of the reporting, also merits the attention of researchers. Finally, we encourage scholars to explore CSR reporting towards internal stakeholders (employees), because internal social responsibility is as relevant as external social responsibility.

\section{NOTES}

${ }^{1}$ We have estimated Models 1 and 2 using other control variables, but the two models used to test the hypotheses are the most significant.

\section{REFERENCES}

Adams, R. \& Funk, P. (2012). Beyond the glass ceiling: Does gender matter?. Management science, 58(2), 219-235.

Ali, M., Ng, Y.L. \& Kulik, C.T. (2014). Board age and gender diversity: A test of competing linear and curvilinear pPredictions. Journal of Business Ethics, 125(3), 497-512.

Alonso-Almeida, M.M., Perramon, J. \& Bagur, LL. (2015). Women managers and corporate social responsibility (CSR) in Spain: Perceptions and drivers. Women's Studies International Forum, 50, 47-56.

Alonso-Almedia, M. M., Perramon, J. \& Bagur-Femenias, LL. (2017). Leadership styles and corporate social responsibility management: Analysis from a gender perspective. Business Ethics: A European Review, 26(2), 147-161.

Al-Shaer, H. \& Zaman, M. (2016). Board gender diversity and sustainability reporting quality. Journal of Contemporary Accounting \& Economics, 12(3), 210-222.

Arellano, M. (2003). Panel Data Econometrics. Oxford: Oxford University Press.

Arora, P. \& Dharwadkar, R. (2011). Corporate governance and corporate social responsibility (CSR): The moderating roles of attainment discrepancy and organization slack. Corporate Governance: An International Review, 19(2), 136-152.

Arosa, B., Iturralde, T. \& Maseda, A. (2010). Ownership structure and firm performance in non-listed firms: Evidence from Spain. Journal of Family Business Strategy, 1(2), 8896. 
Ayuso S. \& Argandoña A. (2007). Responsible corporate governance: Towards a stakeholder board of directors?. Working Paper No. 701, IESE Business School, Barcelona, July.

Bolton, P., Becht, M. \& Röell, A. (2002). Corporate Governance and Control. No. w9371. National Bureau of Economic Research.

Cabeza-García, L., Fernández-Gago, R. \& Nieto, M. (2017). Do board gender diversity and director typology impact CSR reporting?. European Management Review. DOI: https://doi.org/10.1111/emre.12143.

Carcello, J.V. \& Neal, T.L. (2000). Audit committee composition and auditor reporting. The Accounting Review, 75(4), 453-467.

Carter, D.A., Simkins, B.J. \& Simpson, W.G. (2003). Corporate governance, board diversity, and firm value. The Financial Review, 38(1), 33-53.

Catalyst (1995). The CEO View: Women on Corporate Boards. New York: Catalyst.

Chava, S. (2014). Environmental externalities and cost of capital. Management Science, 60(9), 2223-2247.

Cuadrado-Ballesteros, B., Rodríguez-Ariza, L. \& García-Sánchez, I.M. (2015a). The role of independent directors at family firms in relation to corporate social responsibility disclosures. International Business Review, 24(5), 890-901.

Cuadrado-Ballesteros, B., Rubio, R. G. \& Ferrero, J. M. (2015b). Efecto de la composición del consejo de administración en las prácticas de responsabilidad social corporativa. Spanish Accounting Review, 18(1), 20-31.

Del Guercio, D. \& Tran, H. (2012). Institutional investor activism, In: Socially Responsible Finance and Investing: Financial Institutions, Corporations, Investors, and Activists, Eds. H. Kent Baker and John Nofsinger, 359-380, John Wiley \& Sons.

Dhaliwal, D.S., Li, O.Z., Tsang, A. \& Yang, Y.G. (2011). Voluntary nonfinancial disclosure and the cost of equity capital: The initiations of corporate social responsibility reporting. The Accounting Review, 86, 59-100.

Dimson, E., Karakaş, O. \& Li, X. (2015). Active Ownership. Review of Financial Studies, 28, 3225-3268.

Dobbin, F., \& Jung, J. (2011). Corporate board gender diversity and stock performance: The competence gap or institutional investor bias?. North Carolina Law Review, 89, 809838.

Dong, S., Burritt, R. \& Qian, W. (2014). Salient stakeholders in corporate social responsibility reporting by Chinese mining and minerals companies. Journal of Cleaner Production, 84, 59-69. 
Dyck, A., Links, K.V. Roth, L. \& Wagner, H.F. (2015). Do institutional investors drive corporate social responsibility? International Evidence. (August 11, 2016). Rotman School of Management Working Paper No. 2708589. Available at: http://dx.doi.org/10.2139/ssrn.2708589

Eagly, A.H., Johannesen-Schmidt, M.C. \& Van Engen, M.L. (2003). Transformational, transactional, and laissez-faire leadership styles: A meta-analysis comparing women and men. Psychological Bulletin, 129, 569-591.

Feng, Z.Z. \& Song, L. (2013). Heterogeneous institution, nature of firm and CSR disclosure. Journal of Shanxi Finance and Economics University, 12, 008.

Fernandez-Feijoo, B., Romero, S. \& Ruiz, S. (2012). Does board gender composition affect corporate social responsibility reporting?. International Journal of Business and Social Science, 3(1), 31-38.

Fernandez-Feijoo, B., Romero, S. \& Ruiz, S. (2014a). Women on boards: Do they affect sustainability reporting?. Corporate Social Responsibility and Environmental Management, 21(6), 351-364.

Fernandez-Feijoo, B., Romero, S. \& Ruiz, S. (2014b). Commitment to corporate social responsibility measured through global reporting initiative reporting: factors affecting the behavior of companies. Journal of Cleaner Production, 81, 244-254.

Fernández-Gago, R., Cabeza-García, L. \& Nieto, M. (2016). Corporate social responsibility, board of directors, and firm performance: An analysis of their relationships. Review of Managerial Science, 10(1), 85-104.

Ferrarini, G. \& Filippelli, M. (2013). Independent directors and controlling shareholders. Orizzonti Del Diritto Commerciale, ISSN 2282-667X.

Fligstein, N. (1991). 'The structural transformation of American industry: An institutional account of the causes of diversification in the largest firms, 1919-1979'. In W. W. Powell \& P. J. DiMaggio (Eds.), The new institutionalism in organizational analysis: 311-36. Chicago, IL: University of Chicago Press.

Frink, D.D., Robinson, R.K., Reithel, B. Arthur, M.M. \& Ammeter, A.P. (2003). Gender demography and organization performance A two-study investigation with convergence. Group \& Organization Management, 28(1), 127-147.

Garcia-Sanchez, I.M., Cuadrado-Ballesteros, B. \& Sepulveda, C. (2014). Does media pressure moderate CSR disclosures by external directors?, Management Decision, 52(6), 10141045. 
Ghabayen, M.A. Mohamada, N.R. \& Ahmadb, N. (2015). Institutional Directors and Corporate Social Responsibility Disclosure in the Jordanian Banks. International Conference on Accounting Studies (ICAS) 2015. 17-20 August 2015, Johor Bahru, Johor, Malaysia.

Good Governance Code of Listed Companies (GGC). (2015). Acuerdo del Consejo de la Comisión Nacional del Mercado de Valores de 18 de febrero de 2015. Madrid, Spain.

Gray, R.H., Owen, D.L. \& Adams, C.A. (1996). Accounting and Accountibility, Changesand Challenges in Corporate Social and Environmental Reporting. 1 edn. Europe: Prentice Hall.

Griffin, J.J. (2017). Tracing stakeholder terminology then and now: Converge and new pathways. Business Ethics: A European Review, 26(4), 326-346.

Hammann, E.M, Habisch, A. \& Pechlaner, H. (2009). Values that create value: socially responsible business practices in SMEs-empirical evidence from German companies. Business Ethics: A European Review, 18(1), 37-51.

Haniffa, R.M. \& Cooke, T.E. (2005). The impact of culture and governance on corporate social reporting. Journal of Accounting and Public Policy, 24(5), 391-430.

Harjoto, M. \& Jo, H. (2011). Corporate governance and CSR nexus. Journal of Business Ethics, 100(1), 45-67.

Harjoto, M., Laksmana, I. \& Lee, R. (2015). Board Diversity and Corporate Social Responsibility. Journal of Business Ethics, 132(4), 641-660.

Hartzell, J.C. \& Starks, L.T. (2003). Institutional investors and executive compensation. Journal of Finance, 58(6), 2351-2374.

Hassan, M. K., Miglietta, F., Paltrinieri, A., \& Floreani, J. (2018). The effects of Shariah board composition on Islamic equity indices' performance. Business Ethics: A European Review, DOI: https://doi.org/10.1111/beer.12185

Hillman, A.J. \& Dalziel, T. (2003). Boards of directors and firm value: Integrating agency and resource dependence perspectives. Academy of Management Review, 28(3), 383-396.

Hwang, C.Y., Titman, S. \& Wang, Y. (2015). Investor tastes, corporate behavior and stock returns: An analysis of corporate social responsibility. Corporate Behavior and Stock Returns: An Analysis of Corporate Social Responsibility (February 3, 2015), DOI: http://dx.doi.org/10.2139/ssrn.2559590

Hyun, E., Yang, D., Jung, H. H. \& Hong, K. (2016). Women on boards and corporate social responsibility. Sustainability, 8(300), 1-26. 
Ivanova, M.R. (2017). Institutional investors as stewards of the corporation: Exploring the challenges to the monitoring hypothesis. Business Ethics: A European Review, 26(2), 175-188.

Jain, T. \& Jamali, D. (2016). The effect of corporate governance on corporate social responsibility. Corporate Governance: An International Review, 45, 102-123.

Jamali, D., El Dinari, A.M. \& Harwood, I.A. (2015). Exploring human resource management roles in corporate social responsibility: the CSR-HRM co-creation model. Business Ethics: A European Review, 24(2), 125-143.

Jamali, D. \& Neville, B. (2011). Convergence vs divergence in CSR in developing countries: An embedded multi-layered institutional lens. Journal of Business Ethics, 102, 599621.

Jamali, D., Lund-Thomsen, P. \& Jeppesen, S. (2017). SMEs and CSR in developing countries. Business \& Society, 56(1), 11-22.

Jo, H., Song, M.H. \& Tsang, A. (2016). Corporate Social Responsibility and stakeholder governance around the world. Global Finance Journal, 29, 42-69.

Kesner, I.F. (1988). Directors' characteristics and committee membership: An investigation of type, occupation, tenure, and gender. Academy of Management Journal, 31, 66-84.

Knouse, S.B. \& Dansby, M.R. (1999). Percentage of work-group diversity and work-group effectiveness. The Journal of Psychology, 133, 486-494.

Kravitz, D.A. (2003). More women in the workplace: Is there a payoff in firm performance?. Academy of Management Executive, 17(3), 148-149.

Landry, E.E., Bernardi, R.A. \& Bosco, S.M. (2016). Recognition for sustained corporate social responsibility: female directors make a difference. Corporate Social Responsibility and Environmental Management, 23(1), 27-36.

Lau, D. C. \& Murnighan, J. K. (1998). Demographic diversity and faultiness: The compositional dynamics of organizational groups. Academy of Management Review, 23, $325-340$.

Li, H. \& Chen, P. (2018). Board gender diversity and firm performance: The moderating role of firm size. Business Ethics: A European Review. DOI: https://doi.org/10.1111/beer.12188.

Liao, L., Lin, T.P. \& Zhang, Y. (2016). Corporate Board and Corporate Social Responsibility Assurance: Evidence from China. Journal of Business Ethics, 1-15. 
Lock, I. \& Seele, P. (2016). The credibility of CSR (corporate social responsibility) reports in Europe. Evidence from a quantitative content analysis in 11 countries. Journal of Cleaner Production, 122, 186-200.

Lückerath-Rovers, M. (2013). Women on boards and firm performance. Journal of Management \& Governance, 17(2), 491-509.

Luoma, P. \& Goodstein, J. (1999). Stakeholders and corporate boards: Institutional influences on board composition. Academy of Management Journal, 42, 553-563.

Mackie, D. M. (1987). Systematic and non-systematic processing of majority and minority persuasive communications. Journal of Personality and Social Psychology, 53, 41-52.

Miller, N. \& Brewer, M.B. (1996). Intergroup relations. Buckingham: Open University Press.

Manzoor, A. \& Abrar, N. (2011). The Difference between female and male leadership. Pakistan Journal of Gender Studies, 5, 41-53.

McNamara, T.K., Carapinha, R., Pitt-Catsouphes, M., Valcour, M. \& Lobel, Sh. (2017). Corporate social responsibility and employee outcomes: The role of country context. Business Ethics: A European Review, 26(4), 413-427.

Mohamad, N.R., Abdullah, S. Mokhtar, M.Z. \& Kamil, N.F.B. (2011). The effects of board independence, board diversity and corporate social responsibility on earnings management. Finance and Corporate Governance Conference. Paper. DOI: http://dx.doi.org/10.2139/ssrn.1725925

Muttakin, M.B., Khan, A. \& Mihret, D.G. (2016). The effect of board capital and CEO power on corporate social responsibility disclosures. Journal of Business Ethics, 1-16.

Neubaum, D.O. \& Zahra, S.A. (2006). Institutional ownership and corporate social performance: The moderating effects of investment horizon, activism, and coordination. Journal of Management, 32(1), 108-131.

Nielsen, S. \& Huse, M. (2010). Women directors' contribution to board decision-making and strategic involvement: The role of equality perception. European Management Review, 7, 16-29.

Oh, W.Y., Chang, Y.K. \& Martynov, A. (2011). The effect of ownership structure on corporate social responsibility: Empirical evidence from Korea. Journal of Business Ethics, 104(2), 283-297.

Ozkan, N. (2007). Do corporate governance mechanisms influence CEO compensation?. An empirical investigation of UK companies. Journal of Multinational Financial Management, 17(5), 349-364. 
Pelled, L.H. (1996). Demographic diversity, conflict, and work group outcomes: An intervening process theory. Organization Science, 7(6), 615-631.

Pucheta-Martínez, M.C. \& López-Zamora, B. (2017). Corporate social responsibility strategies of Spanish listed firms and controlling shareholders' representatives. Organization \& Environment, https://doi.org/10.1177/1086026617722147.

Reguera-Alvarado, N., de Fuentes, P. \& Laffarga, J. (2015). Does board gender diversity influence financial performance?. Evidence from Spain. Journal of Business Ethics, 141(2), 337-350.

Richard, O.C., Murthi, B.P.S. \& Ismail, K. (2007). The impact of racial diversity on intermediate and long-term performance: The moderating role of environmental context. Strategic Management Journal, 28, 1213-1233.

Rodríguez-Ariza, L., Cuadrado-Ballesteros, B., Martínez-Ferrero, J. \& García-Sánchez, I.M. (2017). The role of female directors in promoting CSR practices: An international comparison between family and non-family businesses. Business Ethics: A European Review, 26(2), 162-174.

Ruiz-Mallorqui, M.V. \& Santana-Martín, D.J. (2011). Dominant institutional owners and firm value. Journal of Banking and Finance, 35(1), 118-129.

Samara, G., \& Arenas, D. (2017). Practicing fairness in the family business workplace. Business Horizons, 60(5), 647-655.

Samara, G., \& Berbegal-Mirabent, J. (2017). Independent directors and family firm performance: does one size fit all?. International Entrepreneurship and Management Journal, 14(1), 149-172.

Samara, G., Jamali, D., Sierra, V., \& Parada, M. J. (2018). Who are the best performers?. The environmental social performance of family firms. Journal of Family Business Strategy, 9(1), 33-43.

Shaukat, A., Qiu, Y. \& Trojanowski, G. (2015). Board attributes, Corporate Social Responsibility strategy, and corporate environmental and social performance. Journal of Business Ethics, 135(3), 569-585.

Shukeri, S.N., Ong, W.S. \& Shaari, M.S. (2012). Does board of director's characteristics affect firm performance?. Evidence from Malaysian public listed companies. International Business Research, 5, 120-127.

Tajfel, H. \& Turner, J. C. (1986). The social identity theory of intergroup behavior. In S. Worchel \& WG Austin (Eds.), Psychology of intergroup relations: 7-24. Chicago: Nelson-Hall. 
Terjesen, S., Sealy, R. \& Singh, V. (2009). Women directors on corporate board: A review and research agenda. Corporate Governance: An International Review, 17(3), 320337.

Thomsen, S. \& Conyon, M. (2012). Corporate governance: Mechanisms and systems. Ed. McGraw-Hill Education, UK.

Unified Code of Corporate Governance (UCCG). (2006). Informe del grupo especial de trabajo sobre buen gobierno de las sociedades cotizadas. Comité Conthe. Madrid, Spain.

Vashchenko, M. (2017). An external perspective on CSR: What matters and what does not?. Business Ethics: A European Review, 26(4), 396-412.

Villalonga, B. \& Amit, R. (2006). How do family ownership, control and management affect firm value?. Journal of Financial Economics, 80(2), 385-417.

Wang, C., Xie, F. \& Zhu, M. (2015). Industry expertise of independent directors and board monitoring. Journal of Financial and Quantitative Analysis, 50(5), 929-962.

Weinstein, D.E. \& Yafeh, Y. (1998). On the costs of a bank-centered financial system: Evidence from the changing bank relations in Japan. Journal of Finance, 53(4), 635672.

Wen, S. (2009). Institutional investor activism on socially responsible investment: effects and expectations. Business Ethics: A European Review, 18(3), 308-333.

Zattoni, A. (2011). Who should control a corporation? Toward a contingency stakeholder model for allocating ownership rights. Journal of Business Ethics, 103(2), 255-274.

Table 1

CSR disclosure classification

\begin{tabular}{cl}
\hline Index Score & \\
\hline 0 & CSR information is not disclosed by firms \\
$0.1-0.5$ & CSR information disclosed by firms is moderate \\
$0.6-0.9$ & CSR information disclosed by firms is significant \\
1 & CSR information disclosed by firms is full \\
\hline
\end{tabular}

Source: Own elaboration 
Table 2

Variables description

\begin{tabular}{|c|c|}
\hline Variables & Description \\
\hline CSR_INDEX & $\begin{array}{l}\text { The ratio between the aggregation of } 5 \text { items of CSR, measured each one as a dummy variable, and the total } \\
\text { items considered (5) }\end{array}$ \\
\hline INDEP_WOM & Proportion of independent female directors on board \\
\hline INST_W̄WM & Proportion of institutional female directors on board \\
\hline INDEP & The proportion of independent directors on boards \\
\hline INST & The proportion of institutional directors on boards \\
\hline OWNCON & The ownership concentration in the firm \\
\hline BDSIZE & The number of directors on boards \\
\hline ROA & Operate income before interests and taxes over total assets \\
\hline LEV & Debt over total assets \\
\hline SIZE & The log of total sales \\
\hline SEC1 & Dummy variable: $1=$ Metalworking; $0=$ Otherwise \\
\hline SEC2 & Dummy variable: $1=$ Other manufacturing industries; $0=$ Otherwise \\
\hline SEC3 & Dummy variable: $1=$ New Technologies; $0=$ Otherwise \\
\hline SEC4 & Dummy variable: $1=$ Basic Metal; $0=$ Otherwise \\
\hline SEC5 & Dummy variable: $1=$ Mass media; $0=$ Otherwise \\
\hline SEC6 & Dummy variable: $1=$ Real Estate; $0=$ Otherwise \\
\hline SEC7 & Dummy variable: $1=$ Chemical industry; $0=$ Otherwise \\
\hline SEC8 & Dummy variable: $1=$ Financing and insurance; $0=$ Otherwise \\
\hline SEC9 & Dummy variable: $1=$ Energy and water; $0=$ Otherwise \\
\hline SEC10 & Dummy variable: $1=$ Construction; $0=$ Otherwise \\
\hline SEC11 & Dummy variable: $1=$ Commerce and other services; $0=$ Otherwise \\
\hline SEC12 & Dummy variable: $1=$ Cement, glass and construction material; $0=$ Otherwise \\
\hline SEC13 & Dummy variable: $1=$ Transport and communications; $0=$ Otherwise \\
\hline SEC14 & Dummy variable: $1=$ Agriculture and fisheries; $0=$ Otherwise \\
\hline
\end{tabular}


Table 3

Main Descriptive Statistics

\begin{tabular}{|c|c|c|c|c|c|c|c|}
\hline \multicolumn{8}{|c|}{ Panel A. Continuous variables } \\
\hline Variables & $\mathbf{N}$ & Mean & Std. Dev. & Perc. 25 & Perc. 50 & Perc. 75 & \\
\hline CSR_INDEX & 1312 & 0.147 & 0.272 & 0.000 & 0.000 & 2.000 & \\
\hline INDEP_WOM & 1312 & $3.176 \%$ & 6.456 & $0.000 \%$ & $0.000 \%$ & $0.000 \%$ & \\
\hline INST_WOM & 1312 & $4.554 \%$ & 7.993 & $0.000 \%$ & $0.000 \%$ & $8.333 \%$ & \\
\hline INDEP & 1312 & $30.271 \%$ & 19.160 & $18.750 \%$ & $30.000 \%$ & $41.176 \%$ & \\
\hline INST & 1312 & $44.693 \%$ & 24.014 & $25.833 \%$ & $44.444 \%$ & $62.500 \%$ & \\
\hline OWNCON & 1312 & $43.667 \%$ & 27.641 & $19.009 \%$ & $41.9112 \%$ & $65.417 \%$ & \\
\hline BDSIZE & 1312 & 10.200 & 3.840 & 8.000 & 10.000 & 12.000 & \\
\hline ROA & 1312 & $2.555 \%$ & 18.595 & $-1.056 \%$ & $2.616 \%$ & $7.850 \%$ & \\
\hline LEV & 1312 & $53.191 \%$ & 34.945 & $31.644 \%$ & $52.915 \%$ & $70.854 \%$ & \\
\hline SIZE & 1312 & 10.561 & 3.219 & 9.283 & 11.002 & 12.924 & \\
\hline \multicolumn{8}{|c|}{ Panel B. Dummies variables } \\
\hline & & & & & 1 & & (1) $\%$ \\
\hline SEC1 & & & & & 109 & & $8.308 \%$ \\
\hline SEC2 & & & & & 309 & & $23.552 \%$ \\
\hline SEC3 & & & & & 99 & & $7.546 \%$ \\
\hline SEC4 & & & & & 49 & & $3.735 \%$ \\
\hline SEC5 & & & & & 43 & & $3.277 \%$ \\
\hline SEC6 & & & & & 173 & & $13.186 \%$ \\
\hline SEC7 & & & & & 34 & & $2.591 \%$ \\
\hline SEC8 & & & & & 55 & & $4.192 \%$ \\
\hline SEC9 & & & & & 123 & & $9.375 \%$ \\
\hline SEC10 & & & & & 79 & & $6.021 \%$ \\
\hline SEC11 & & & & & 122 & & $9.299 \%$ \\
\hline SEC12 & & & & & 40 & & $3.049 \%$ \\
\hline SEC13 & & & & & 56 & & $4.268 \%$ \\
\hline SEC14 & & & & & 21 & & $1.601 \%$ \\
\hline
\end{tabular}

Mean, standard deviation and percentiles. Panel A and B show the continuous and dummy variables, respectively. CSR_INDEX is measured as the ratio between the aggregation of the 5 items of CSR considered, measured each one as a dummy variable and the total items (5); INDEP_WOM is the proportion of independent female directors on board; INST_WOM is the proportion of institutional female directors on board.; INDEP is the proportion of independent directors on the boards; INST is the proportion of institutional directors on boards; OWNCON is the ownership concentration in the firm; BDSIZE is the number of directors on boards; ROA is the Operate income before interests and taxes over total assets; LEV is the debt over total assets; SIZE is the log of total sales; SEC1 1 if the company operates in metalworking sector and 0, otherwise; SEC2 1 if the company operates in other manufacturing industries sector and 0, otherwise; SEC3 1 if the company operates in new technologies sector and 0, otherwise; SEC4 1 if the company operates in basic metal sector and 0, otherwise; SEC5 1 if the company operates in mass media sector and 0, otherwise; SEC6 1 if the company operates in real estate sector and 0, otherwise; SEC7 1 if the company operates in chemical industry sector and 0, otherwise; SEC8 1 if the company operates in financing and insurance sector and 0, otherwise; SEC9 1 if the company operates in energy and water sector and 0, otherwise; SEC10 1 if the company operates in construction sector and 0, otherwise; SEC11 1 if the company operates in commerce and other services sector and 0, otherwise; SEC12 1 if the company operates in cement, glass and construction material sector and 0, otherwise; SEC13 1 if the company operates in transport and communications sector and 0, otherwise; SEC14 1 if the company operates in agriculture and fishing sector and 0, otherwise. Significant at $* * *$ for 99 percent confidence level, ** for 95 percent and * for 90 percent. 
Table 4

Results of the Tobit regressions for independent and institutional women directors on boards

\begin{tabular}{|c|c|c|c|c|c|}
\hline & \multirow{2}{*}{ Expected sign } & \multicolumn{2}{|c|}{ Model 1} & \multicolumn{2}{|c|}{ Model 2} \\
\hline & & Coefficient & p-value & Coefficient & p-value \\
\hline INDEP_WOM & + & $2.551 * * *$ & 0.000 & & \\
\hline INDEP_WOM ${ }^{2}$ & - & $-6.231 * * *$ & 0.004 & & \\
\hline INST_WOM & + & & & $1.235^{*}$ & 0.056 \\
\hline INST_WOM $^{2}$ & & & & $-4.637 *$ & 0.077 \\
\hline INDEP & + & 0.213 & 0.132 & $0.413 * * *$ & 0.002 \\
\hline INST & $+/-$ & $-0.380 * * *$ & 0.000 & $-0.406^{* * *}$ & 0.000 \\
\hline OWNCON & + & $0.260 * * *$ & 0.001 & $0.263 * * *$ & 0.001 \\
\hline BDSIZE & + & $0.033 * * *$ & 0.001 & $0.063 * * *$ & 0.000 \\
\hline ROA & + & $0.362 * *$ & 0.031 & $0.393 * *$ & 0.023 \\
\hline LEV & + & 0.058 & 0.393 & 0.038 & 0.583 \\
\hline SIZE & + & $0.033 * * *$ & 0.001 & $0.037 * * *$ & 0.001 \\
\hline SEC1 & $+/-$ & $-1.331 * * *$ & 0.000 & $-1.395 * * *$ & 0.000 \\
\hline SEC2 & $+/-$ & $-0.994 * * *$ & 0.000 & $-1.395 * * *$ & 0.000 \\
\hline SEC3 & $+/-$ & $-1.517 * * *$ & 0.000 & $-1.007 * * *$ & 0.000 \\
\hline SEC4 & $+/-$ & $-1.093 * * *$ & 0.000 & $-1.121 * * *$ & 0.000 \\
\hline SEC5 & $+/-$ & $-1.531 * * *$ & 0.000 & $-1.566 * * *$ & 0.000 \\
\hline SEC6 & $+/-$ & $-1.219 * * *$ & 0.000 & $-1.325 * * *$ & 0.000 \\
\hline SEC7 & $+/-$ & $-1.610 * * *$ & 0.000 & $-1.660 * * *$ & 0.000 \\
\hline SEC 8 & $+/-$ & $-0.933 * * *$ & 0.000 & $-0.971 * * *$ & 0.000 \\
\hline SEC9 & $+/-$ & $-0.761 * * *$ & 0.000 & $-0.821 * * *$ & 0.000 \\
\hline SEC10 & $+/-$ & $-1.305 * * *$ & 0.000 & $-1.315 * * *$ & 0.000 \\
\hline SEC11 & $+/-$ & $-1.376^{* * *}$ & 0.000 & $-1.385 * * *$ & 0.000 \\
\hline SEC12 & $+/-$ & $-0.993 * * *$ & 0.000 & $-1.049 * * *$ & 0.000 \\
\hline SEC13 & $+/-$ & $-1.684 * * *$ & 0.000 & $-1.758 * * *$ & 0.000 \\
\hline $\begin{array}{l}\text { Observations } \\
\mathrm{R}^{2}\end{array}$ & & $\begin{array}{r}13 \\
43.4\end{array}$ & & & \\
\hline
\end{tabular}

CSR INDEX is measured as the ratio between the aggregation of the 5 items of CSR considered, measured each one as a dummy variable and the total items (5); INDEP_WOM is the proportion of independent female directors on board; INST_WOM is the proportion of institutional female directors on board.; INDEP is the proportion of independent directors on the boards; INST is the proportion of institutional directors on boards; OWNCON is the ownership concentration in the firm; BDSIZE is the number of directors on boards; ROA is the Operate income before interests and taxes over total assets; LEV is the debt over total assets; SIZE is the log of total sales; SEC1 1 if 
the company operates in metalworking sector and 0, otherwise; SEC2 1 if the company operates in other manufacturing industries sector and 0, otherwise; SEC3 1 if the company operates in new technologies sector and 0, otherwise; SEC4 1 if the company operates in basic metal sector and 0, otherwise; SEC5 1 if the company operates in mass media sector and 0, otherwise; SEC6 1 if the company operates in real estate sector and 0, otherwise; SEC7 1 if the company operates in chemical industry sector and 0, otherwise; SEC 81 if the company operates in financing and insurance sector and 0, otherwise; SEC9 1 if the company operates in energy and water sector and 0, otherwise; SEC10 1 if the company operates in construction sector and 0, otherwise; SEC11 1 if the company operates in commerce and other services sector and 0 , otherwise; SEC12 1 if the company operates in cement, glass and construction material sector and 0, otherwise; SEC13 1 if the company operates in transport and communications sector and 0, otherwise; SEC14 1 if the company operates in agriculture and fishing sector and 0 , otherwise. Levels of significance: $* * * \mathrm{p}<0,01 ; * * \mathrm{p}<0,05 ; * \mathrm{p}<0,10$.

Figure 1

Summary of the main findings

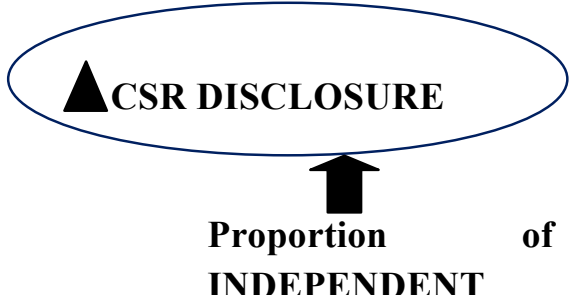

INDEPENDENT

female directors

from $0 \%$ to $20.47 \%$

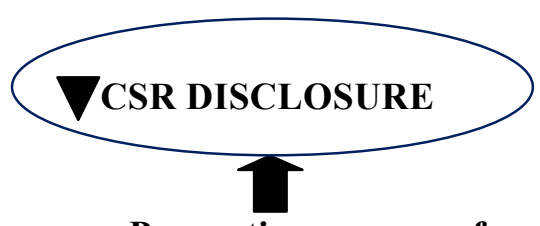

Proportion of

INDEPENDENT

female directors from $20.47 \%$ to $100 \%$

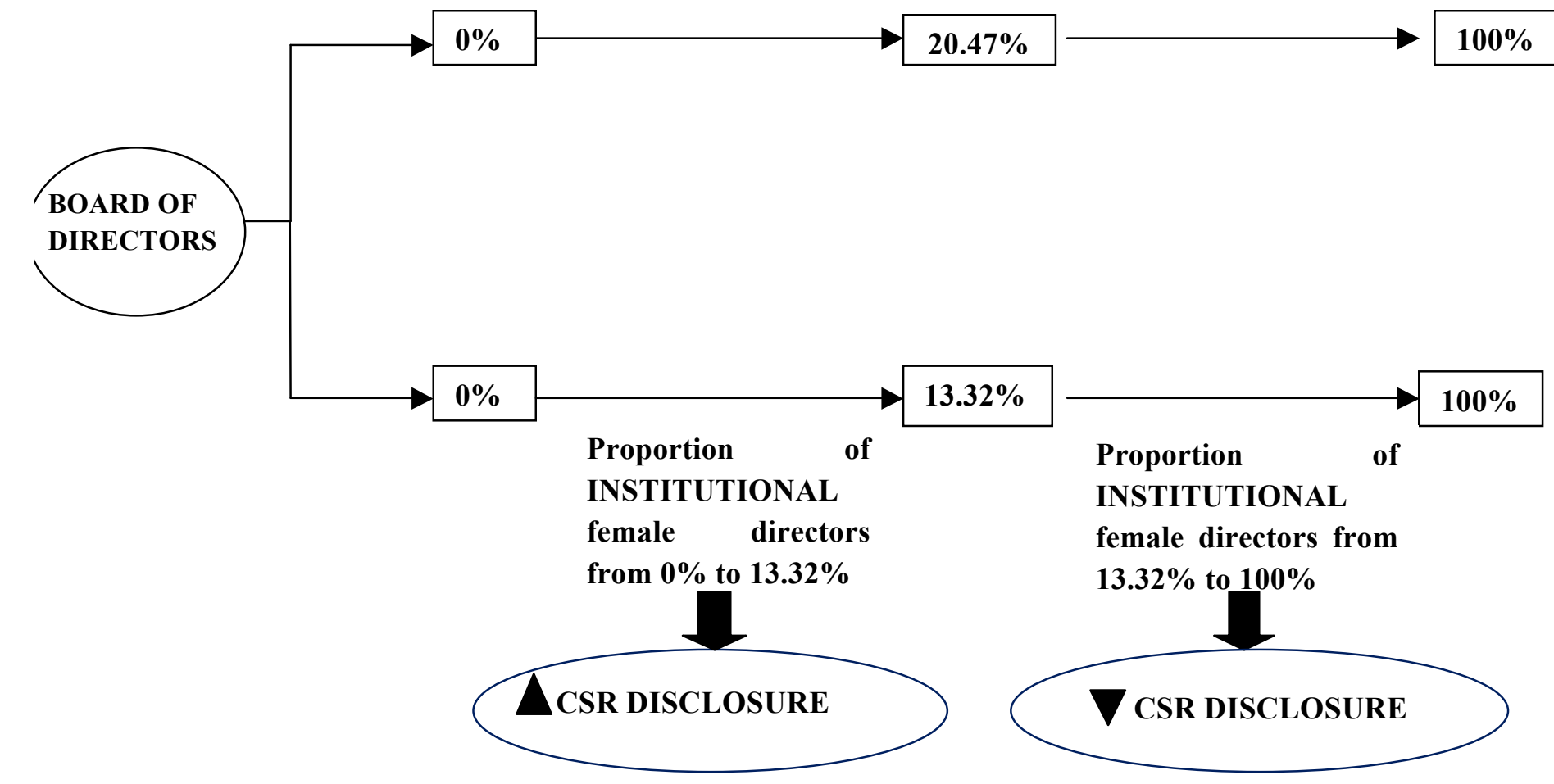

